\title{
Allogeneic Conditioning
}

National Cancer Institute

\section{Source}

National Cancer Institute. Allogeneic Conditioning. NCI Thesaurus. Code C107095.

A preparative treatment regimen given prior to a cell transplantation from a genetically non-identical donor. The regimen consists of chemotherapy with or without radiation and is intended to kill cancerous cells before the transplantation and to provide immunosuppression to prevent the rejection of the donor's stem cells. 